\title{
THEORY OF NEEDS AS JUSTIFICATION OF HUMAN RIGHTS: CURRENT APPROACHES AND PROBLEMS OF UNCERTAINTY AND NORMATIVENESS*
}

\author{
MARTIN HAPLA**
}

\begin{abstract}
This paper deals with the theory of needs as a possible justification of human rights. First, it defines the concept of need, which differs from the concept of want. It states that need is, by definition, objective in nature. The paper then analyses some concepts of need (especially those of David Miller and Massimo Renzo) and examines their advantages and disadvantages in relation to justification theories (for example James Griffin's approach which is based on the idea of normative agency). According to the author, these concepts have natural-law foundations and cannot deal, in particular, with the problem of transition from facts to norms. In addition, the requirements that we usually derive from needs retain too much uncertainty. In spite of these shortcomings, using them as arguments in law and even more in politics retains a great convincing power. Its sources are difficult to identify, however, it is an important concept we use in everyday life (though in a shifted meaning). Finally, the author concludes that although needs are not able to establish human rights in a satisfactory way - provided we renounce the universal nature of these rights - they can play a very useful and important role in justifying them in certain local contexts.
\end{abstract}

Keywords: Human rights; needs; basic needs; justification; natural law; normativeness.

Summary: I. InTRODUCTION; II. THE CONCEPT OF NEED; III. BASIC NEEDS AS JUSTIFICATION OF HUMAN RIGHTS; III.1 David Miller's Approach; III.2 Massimo Renzo's Approach; III.3 The Relationship of Theories of Needs and Other Justification Approaches; IV. BASIC NEEDS AND THEIR RELATION TO THE CONCEPT OF Rights; IV.1 The Problem of Uncertainty; IV.2 The Problem of Normativeness; V. CONVINCINGNESS OF BASIC NEEDS; VI. CONCLUSION.

\section{INTRODUCTION ${ }^{* * *}$}

There is no doubt that human rights are currently an extremely influential concept. If governments today commit cruel or unjust actions, we refer to violations of human rights, rather than that they are unjust, immoral, or barbaric (Nickel, 2007: 1; Kysela, 2014: 258). The very use of this term in English-written books has increased 200 times since 1940, and is currently being used 100 times more often than expressions such as constitutional rights or natural rights (Posner, 2014: 6). Both point out that human rights are an influential rhetoric - not only in the legal and political practice, but also in its theoretical reflection. But is there actually anything behind it? Is it not just a pretty facade

\footnotetext{
* The paper was written as an output from the project Axiologické základy právního myšlení (code: MUNI/A/0828/2016).

** JUDr. Martin Hapla, Ph.D; an assistant professor at the Department of Legal Theory, Faculty of Law, Masaryk University (martinhapla@gmail.com).

***I would like to thank to my dear colleagues, Mgr. Pavel Dufek, Ph.D.; doc. Mgr. Marek Káčer, PhD., and JUDr. Pavel Ondřejek, Ph.D. for their valuable and stimulating comments that enabled me to significantly improve my original text.
} 
of a house whose interior has deeply decayed? The frequency and manner in which these rights are used in today's discourse undoubtedly testify that they have considerable influence on us and that they are in some sense very convincing, but they no longer tell us anything about whether we have good reasons to accept them. It is precisely in possible doubts about the validity of our reasons that we can see a certain deficit. Many authors (Neumann, 1992: 353; Freeman, 2004: 392) have pointed out that we do not know what exactly is the basis of these rights ${ }^{1}$. The idea that it is worth asking the question of their justification remains a serious notion. For example, Jan Broz and Pavel Ondřejek put such questions into the context of search for the scope and limitations of these rights, attributing a possible positive impact on the coherent application of the law (Broz and Ondrejek, 2016: 202) ${ }^{2}$ Carl Wellman then points out that the formulation of human rights is highly abstract, and if we want to derive specific duties and obligations from them, it is identification of their foundation that can help us to specify them (Wellman, 2011: v). Theoretical reflection on human rights issues is certainly not a problem in itself - it also has practical consequences.

There are countless possible ways to deal with this justification deficit (Hapla, 2016: 89 et seq.). One is the effort to bring closer the concepts of human rights and basic needs. The very idea that we have certain basic needs from which our rights somehow derive seems to be very intuitive. The interconnection of both of these categories takes place on a different basis. For example, Michael Neumann perceives the theory of needs even as a possible third path - an alternative to utilitarianism and right theories (Neumann, 1992: 354); an insight that may correspond with a more general attitude that supports the notion that human needs formulate the ontological foundation for the values protected by the legal order (Zetterbaum, 1977: 989). The idea that needs-based justification is capable of establishing human rights objectively and universally is currently proposed by, for example, David Miller (2017: 179; 2012: 410 - 411), Rita Floyd (2011: 103), and Massimo Renzo (Renzo, 2015: 572). On the contrary, other authors such as H. J. McCloskey or Jeremy Waldron, examine the very relationship of needs and rights, arriving to sceptical conclusions that emphasize that rights cannot be fully explained in terms of needs (McCloskey, 1976: 1; Waldron, 2000: 116 et seq).

The main objective of this paper is therefore to explore whether a concept of needs can be a credible basis for the justification of human rights and their subsequent realization. The greatest attention will be paid to the most serious and most illustrative attempts recently made in connecting theories of needs and rights, which are the conceptions of David Miller and Massimo Renzo. This objective corresponds with the very structure of the paper. The first part of the paper addresses the concept of needs and the second introduces key conceptions that use it. The third part outlines its relationship with natural-right theories and examines its advantages and disadvantages compared to the concept of human rights and other forms of their justification. In the final part of the paper, an attempt is made to identify the causes of its great convincingness. The final

\footnotetext{
${ }^{1}$ Various concepts of the source of human rights were recently nicely summarized by, for instance, Rowan Cruft, S. Matthew Liao and Massimo Renzo (2015: 702).

${ }^{2}$ Further compare some arguments by Pavel Ondřejek (2013: 28) that he uses to prove the necessity to address the theoretical framework of fundamental rights.
} 
thesis, which I would like to introduce to readers, is that needs are not able to establish human rights in a satisfactory way since they have strong natural-law roots, the criticism of which they cannot cope with. On the other hand, if we renounce the universal dimension of these rights, needs can play a very useful and important role in justifying them in certain local contexts.

\section{THE CONCEPT OF NEED}

If we talk about needs in common language, we do not always mean the same thing. Often, we use this word in a figurative sense or interchange it with a number of other but not the same terms. The first necessary clarification in connection with needs is that we must distinguish the meaning in terms of a statement of the type "engine needs more oil," and in terms of claims about the needs of living organisms. If we say that an engine needs something, it does not mean that it has that need (McCloskey, 1946: 3). Therefore, when we talk about needs in other parts of this paper, it will primarily mean the needs of living creatures, namely people's needs. ${ }^{3}$ Another general point is that the goal of such needs is not commodities but their effects on human life (Stewart, 1989: 354 and 368). Considering, for example, the need to eat, it is clear that a tall and strong man needs more food to satisfy the need than a tiny and fragile woman. The amount of commodity will therefore be very different in both cases, but the effects on their lives will be the same.

It is important to distinguish two ways in which we usually use the word need. For example, Jeremy Waldron distinguishes needs in the instrumental and categorical sense. ${ }^{4}$ The first one can be formulated by stating that, "P needs $\mathrm{X}$ to reach $\mathrm{Y}$." $\mathrm{X}$ therefore appears to be a necessary condition for achieving Y (Waldron, 2000: 119). An example of such a construction may be the claim that a drug addict needs a drug to achieve euphoria. In the second example, needs clearly are a narrower concept. This can be described using the construction, " $\mathrm{X}$ is necessary as a minimum condition for $\mathrm{P}$ to have a bearable human life." (Waldron, 2000: 120) ${ }^{5}$ Such categorical needs can, however, be understood as a particular kind of instrumental needs. (Renzo, 2015: 577) ${ }^{6}$ They do not differ from their basic constructions but the objectives they seek. In their case, they are reduced to a bearable human life or a concept of life worth pursuing. What is important is that if we are to consider needs as justification of human rights, we need to limit understanding to needs in a categorical sense - in the context of certain concepts called basic needs. Certainly, nobody would derive from the need of a drug addict their right to use drugs.

\footnotetext{
${ }^{3}$ Here, I would like to point out to the reader in advance that the distinction between the needs of humans and the needs of animals is one of the key problems of theories of needs that seek to justify human rights. I will address this issue later in this text.

${ }^{4}$ With Waldron's differentiation, compare the approach of David Wiggins to distinguishing between purely instrumental needing and needing in absolute or categorical sense (Wiggins, 1998: 7-10).

${ }^{5}$ In his text, Waldron then refers to different variants of the formula in the work of David Miller, Herbert Marcus, and James Griffin.

${ }^{6}$ Compare Massimo Renzo's claim that needs depend on certain goals that we accept (Renzo, 2015: 577).
} 
However, even if we use the term "need" in such a narrow sense, there is still a risk of its possible confusion with other similar terms. It is a precise distinction that can lead us to an adequate understanding of their meaning. The most important thing is to distinguish between needs and wants. The difference between the two was well described by Jeremy Waldron (Waldron, 2000: 129). This author states that a need has an objective character while a want has a subjective character (Waldron, 2000: 129). The former is something necessary and essential that creates respect, while the latter is a matter of our desire and whims. All people need to eat, but some women want to have a nicer nose. One can reasonably ask: I want it, but do I really need it? On the contrary, the strength of our wants is that we are always well aware of them since they are part of our inner experiences. We can be mistaken about our needs (McCloskey, 1976: 4) since they do not have to match what we feel. A need is not a subjectively experienced shortcoming - that a man feels thirsty does not mean he needs to drink. His feeling could be merely a result of a hypothalamus disorder when excessive fluid intake can, on the contrary, greatly harm him. In other words, it makes sense to ask yourself, "Do I really need this?" but not, "Do I really want it?"

In addition to the above, there are even more subtle resolution requirements (Zetterbaum, 1997: 989). ${ }^{7}$ Particularly noteworthy is the differentiation of needs and drives about which McCloskey claims to be potentially destructive in contrast to needs (McCloskey, 1976: 4). A need is by definition something positive and beneficial to us. Greater attention should also be paid to the difference between interests and needs (e.g. Wiggins, 1998: 16-17) ${ }^{8}$ since in certain contexts it may make more sense to speak of the former and not the latter. As a suitable example of such a situation, the aforementioned author uses the statement, "Soccer player Smith needs special boots to win the prize for the best footballer." (McCloskey, 1976: 2) We certainly would not say that Mr. Smith needs those special boots as much he needs to eat or drink. However, he undoubtedly has an interest in having them. Needs relate more to the basic prerequisites of human existence, not to the aspirations individuals can have. We could say that meeting our needs is in our interest (McCloskey, 1976: 8) or that our interests stem from our needs. Certainly not all our interests are needs. They are not only affected by them, but also by goals, aspirations, values, etc. (McCloskey, 1976: 9)

In Rita Floyd's opinion, the definition of need alone may be positive or negative. Positive definition attempts to grasp satisfaction of needs as something essential to human flourishing and objective human well-being. On the contrary, negative definition characterizes needs by claiming that failure to satisfy it causes serious harm (Floyd, 2011: 110). We can perceive the idea of human flourishing as closely related to the idea of a (good, bearable, etc.) human life, which will be given a great deal of attention in other parts of this paper. Let's take a closer a look at the idea that the absence of the necessary is for its essentiality something that could cause us harm. ${ }^{9}$ Such a claim is not entirely

\footnotetext{
${ }^{7}$ For example, according to McCloskey, it is necessary to distinguish luxury, natural instincts, wants, lust, expectations, and even some other categories (McCloskey, 1976: 3 et seq.).

${ }^{8}$ It is true that some authors do not really distinguish between the two concepts. In my view, Massimo Renzo is also one of them (Renzo, 2015: 584).

${ }^{9}$ This view is strongly criticized by McCloskey (1976: 5 - 6), similarly critical is also Griffin (2008: 89 -
} 
appropriate because in extreme cases it could also apply to the absence of the wanted - at least in the sense that its absence could cause us strong psychological frustration. Not every fact that can cause us harm must necessarily be a need, and it is very difficult to define harm about which this would be true (Griffin, 2008: 90). For this reason, it is problematic to link the concepts of need and harm.

To sum up, if we are to consistently differentiate needs from other similar standards, their understanding begins to approach the characteristics of human features that are not subjective in character (compare Wiggins, 1998: 6), and their fulfilment is not associated with negative effects on their lives. It is worth noting that even among the proponents of such a characteristic there is very little consensus on what these features are (Zetterbaum, 1977: 989). ${ }^{10}$ If there is a certain consensus in this respect, it concerns the general characteristics of need rather than what it really is in real life. The problem is therefore noetic. From a conceptual point of view, a need is something objective and positive, but how do we know what a need is in real life? And are there any needs that would meet such a definition?

It is not easy to answer such questions and so the following consideration should be perceived as a sceptical alternative that can be discussed, not as an exhaustive answer. Naturally, some of our wants can also be needs. I can want things that I also need. However, this does not remove the differences between them. There is little consensus on what all falls into the category of our needs (Zetterbaum, 1977: 989). Let's admit that wants can be defined with respect to our inner experiences while needs are defined with regard to some conception of (good, dignified, full) ${ }^{11}$ life. Even in this case, however, there may be countless conceptions of life from which we can hardly pick one that would be correct, except that in their case, too, we can ask ourselves what they are conditioned by or what their basis is. At least some of these may be hedonistic, i.e., addressing our pleasant and unpleasant experiences, bringing them rather closer to certain reflection of our wants as their basis.

Needs are relative to the concept of life, which is a concept that can also evolve. Generally, people tend to intensify what they claim are their needs (MacMillan, 1986: 288). ${ }^{12}$ In the context of social discourse, however, this intensification is limited by the

90).

${ }^{10}$ To this, compare Frances Stewart's differing assertion that there is a disagreement about what basic needs goods are but a general consensus on their core, which includes food, water, health, education, and housing (Stewart, 1989: 348; also compare Stewart, 1985: 1). This is close to the approach of Massimo Renzo (2015: 577) who claims that all people need food, air, water, shelter, minimal health, and a minimum level of social interaction. Renzo identifies such needs as basic. David Miller (2007: 184) states that basic needs include, among others, food and water, clothing and shelter, physical security, health care, education, work and leisure, and freedom of movement, conscience, and expression. Personally, I find it remarkable that Miller refuses to create a definitive list of these needs, which suggests that needs as a concept have an epistemically uncertain boundary.

${ }^{11}$ E.g. Francis Stewart has repeatedly mentioned the relationship between the basic needs approach and the concept of full life (Stewart, 1985: 3-5).

${ }^{12}$ In addition, it would probably be surprising if the successful technical development of the last century has not greatly altered the view of the general society about a good, dignified, or full life. However, by this we accept a different framework of needs and generally recognize more of them than ever before. Finally, 
consensus of its participants. The consensus can only be achieved on some issues. Such a consensus forms a wider shared understanding of human needs and their disruption. If Frances Stewart considers extreme cases of disruption of basic needs (e.g., famine) to be well recognizable and at the same time admits that there is a large grey zone in which it is difficult to draw a clear line between when it is and when it is not disruption of basic needs (Stewart, 1989: 351), these are insights that are largely influenced by social consensus. Surely it would not be right to put an equal sign between needs and wants, but in the real world it cannot be ruled out that the latter is becoming the former in the eyes of the largest part of the people through the functioning of the social arena.

\section{BASIC NEEDS AS JUSTIFICATION OF HUMAN RighTS}

\section{III.1 David Miller's Approach}

The features of needs can be better revealed if we address them in the context of specific theories. The author of the first theory is currently British political theorist David Miller. He distinguishes monistic and pluralist theories of justification of human rights (Miller, 2012: 410 - 411). While the latter admit that human rights can have more grounds, the former claim a single universal ground (Miller, 2012: 410 - 411). Miller himself favours monistic theories since, in his view, pluralist theories can weaken the ethical power of human rights. In addition, conflicts can arise between different grounds of human rights (Miller, 2012: 410 - 411). Miller thus also rejects the overlapping consensus strategy as a way that justification of human rights could cope with cultural diversity (Miller, 2012: 410). On the contrary, he is of the opinion that it is necessary and possible to stick with one universal ground of such rights that we can find in a certain concept of needs.

The main problem Miller has to resolve in his theory is that the range of needs in each culture varies considerably. Indigenous people of a forest tribe do not need the Internet, while the citizens of a European city cannot live without it. Miller notes that although needs are not a matter of choice on an individual level (Miller, 2007: 180), they are on a social level. We have needs as human beings who are anchored in society (Miller, 2012: 412). It is therefore not surprising that needs are more extensive in richer societies than in poorer ones (Miller, 2012: 412). However, this could endanger their universal dimension.

Miller seeks to solve this problem by identifying a core of human needs that does not vary depending on place and time. He is also willing to admit that not all rights that are part of human rights catalogues can be described as truly human rights and derived from needs. Supporters of similar ways of justification often claim to have only minimalist goals and that they only want to defend a certain core of human rights, not solve all the problems and remove all the disagreements that are related to them in various ways (Renzo, 2015: 587). Miller then first distinguishes between instrumental and

it cannot be excluded that in a society of extreme well-being, the need for a nicer nose will also be seriously discussed with an initiative to enshrine a fundamental right to guarantee its satisfaction. 
intrinsic needs. Intrinsic needs are associated with objects or conditions that a person must necessarily have in order to avoid harm. Such a need is for instance food without which people would suffer from malnutrition and hunger (Miller, 2007: 179). This distinction then leads its author to the necessity of defining harm in such a way as to have a universal character (Miller, 2007: 179 - 180). He refuses to grasp it on a biological and psychological basis because people are social beings, which must also be taken into account (Miller, 2007: 181). A person then suffers harm only if they are unable to live a minimally decent life in the society to which they belong (Miller, 2007: 181). David Miller, to a certain extent, combines the positive and negative approach (Floyd, 2011: 110) to defining the concept of needs, but ultimately again refers to some concept of life as their basis.

After excluding instrumental needs, it is still necessary, in his view, to distinguish underlying needs, which remain unchanged and which are universal regardless of place and time, from objects and conditions that must be satisfied and that are variable. This can be expressed on a specific example: everyone has a health need though only some have a specific need for protection against malaria. According to Miller, human rights can be based on such underlying needs (Miller, 2007: 182). This to a certain extent clears the concept of needs and identifies its core which is universal, but at the same time very abstract, and can prove to be problematic in deriving specific requirements.

Later, Miller responds to the same problem with a slightly different resolution of human needs; proper and societas needs. Societas needs are what people have as members of a particular society (Miller, 2012: 413). Even in this case, however, Miller cannot avoid reference to the concept of decent life. In his concept, we should understand needs as something that determines the conditions of such a life. The persons have this life if they are involved in a range of human activities that are reiterated across societies in such a way that it allows us to speak meaningfully about the human form of life (Miller, 2012: 416). Legitimate disagreement, in his opinion, does not exist about needs themselves, but about what they mean in particular situations and what should prevail if two such needs come into conflict (Miller, 2012: 416).

If Miller tries to react in his theory to cultural diversity, which he claims any theory of human rights must take seriously (Miller, 2012: 409), then he cannot avoid other difficulties. What is the meaning of the need for a fixed dwelling place in a nomad society? Miller again deals with this counterexample by defining different types of needs - this time basic and societas, of which the former is universal and the latter linked to a particular society (Miller, 2007: 182). Basic needs to some extent overlap with his former concept of proper human needs. This conceptual distinction represents elaboration on his previous considerations. Human rights are justified only by basic needs, while societas needs justify a wider set of rights of citizenship (Miller, 2007: 182). In other words, they guarantee an individual a certain position as a full member of a particular society (Miller, 2007: 183). In the spirit of this distinction, we can distinguish the wider right to shelter, which is a human right also possessed by nomads, and the narrower right to a fixed dwelling place, which is held only by members of certain societies (Miller, 2007: 183). Basic needs can then be defined as the intersection of societas needs (Miller, 2007: 183). 
However, such an approach does not allow us to reach any definitive and final list of basic needs because societas needs represent a too large and difficult-to-grasp set which, moreover, is subject to continuous development.

Finally, Miller notices that the demands we generate from basic needs have no limit, which in some cases can cause considerable difficulties (especially for needs that demand healthcare to be satisfied). This is because society, no matter how hard it tries, may not be able to satisfy such needs (Miller, 2007: 185). This is, of course, a problematic part of not only Miller's theory but also of other concepts that seek to justify human rights. Usually it is dealt with by inserting certain practical considerations among the existential conditions of human rights (Miller, 2007: 185 - 186). ${ }^{13}$ According to Miller, practical considerations may also have an impact on what rights we derive from our needs (Miller, 2007: 186). ${ }^{14}$ We certainly have the need for love and respect, but it is the practical considerations that require us not to force those needs (Miller, 2007: 187). True love and true respect must have an element of voluntariness. The way human rights are derived from basic needs is thus gaining an important corrective.

Miller's theory hints at their most problematic parts. The fact that Miller's justification works only within a certain limited framework can be solved by accepting the thesis that it is the maximum of possible. However, this does not change the fact that his set of needs is very abstract and it is a question of whether it can provide us with sufficient clues to solve various concrete situations. Fully unresolved then remains the problem of transition from fact to norms. In principle, Miller accepts as a prerequisite that certain needs can be derived from certain requirements (Miller, 2012: 422), without examining it in detail or attempting to justify it.

\section{III.2 Massimo Renzo's Approach}

Massimo Renzo defines his basic needs theory as justification of human rights in relation to James Griffin's concept of normative agency. Griffin claims that we have human rights to protect how we differ from animals - our ability to create and choose concepts of good life. Human rights should therefore allow us to live a human life (Griffin, 2008: 31-33, Renzo, 2015: 573). Renzo then repeats the traditional argument against Griffin's theory which is that many people are not normative agents (typically children, some mentally handicapped, or people suffering from dementia) (Renzo, 2015: 574). ${ }^{15}$ Logically, it would appear that such people are not bearers of human rights. The usual defence in this respect is that they can be bearers of other moral rights that they obtain on a different ground (e.g., because they suffer) (Renzo, 2015: 574). Human rights are not here to deal with and cover all morally sensitive situations. However, the problem remains that if we perceive the torture of children as violation of their dignity and disregard for their humanity, then we need a different concept of what makes human a human than that based on the idea of normative agency (Renzo, 2015: 575). Massimo Renzo claims that such a concept can be based on human needs (Renzo, 2015: 575) since it is able to cope

\footnotetext{
${ }^{13}$ Compare, e.g., the practicalities of James Griffin (2008:35).

${ }^{14} \mathrm{On}$ this and following pages, Miller illustrates his ideas also using various examples.

${ }^{15}$ For example, Ari Kohen (2005: 64) argues similarly against Alan Gewirth's concept.
} 
well with the above (Renzo, 2015: 577). While some mentally handicapped people are not normative agents, they certainly have some needs.

Renzo's concept faces the same problem as most similar approaches - it also relies on the idea, in this particular case, of a minimally decent life that should be understood more broadly than a healthy biological and psychological life (Renzo, 2015: 577). Renzo himself defines it as, "one in which we have the option to fulfil a core group of socially embedded biological and psychological needs, as well as social needs.” (Renzo, 2015: 587) Unfortunately, if we extend the concept of a minimally decent life in such a way, we will have to face the usual epistemic problem of how we know what such a life is like. In addition, there is an argument that asks, what is the difference between the needs of coma patients and animals' needs? If we give rights to such patients, then why not to animals? If we emphasize that people, unlike animals, have some higher needs, it is clear that those who are in the coma do not. Renzo claims that even the biological needs of people have a social dimension (Renzo, 2015: 584). However, it is not entirely clear what he means by this and to what extent it is possible to state this about the above-mentioned examples. This situation could be solved by pointing out that it cannot be considered whether their condition is irreversible since this is given by random factors such as the development of medicine, etc. From a moral point of view, it is necessary to take into account that higher needs are something inherently human and that it is wrong if some people do not have them. There is no such argument about animals. However, accepting this argument also requires accepting its (somewhat controversial) preconditions: If we are to truly accept this concept of needs as meaningful, we cannot go without reference to any form of essentialism. ${ }^{16}$

Renzo states that a minimally decent life is to establish a common standard for all. We might have different life goals and ideas of a good life, but the above concept is minimal and therefore shared by all. It should not be related to any great aspirations or exalted ideas (Renzo, 2015: 579). It is essential that we have to have an opportunity for a minimally decent life and that it is not necessary to realize it. One can refuse to eat merely based on their beliefs (or as part of a political protest). However, in such a case it cannot be said that they do not lead a decent life (Renzo, 2015: 579 - 580).

Finally, Renzo, after analysing various counterexamples contradicting his theory (e.g., that even a tortured man can live a minimally decent life) (Renzo, 2015: 580) states that human rights express rather the worth of a person than the worth of the interests they have. More important is the person themselves than the goals they want to realize. The person is a goal in himself. Human rights can thus be understood as non-instrumental, and their justification can be based on such an understanding (Renzo, 2015: 582). However, if we accept such a concept, is not the concept of needs redundant? Could we do without it in justifying human rights? (Renzo, 2015: 582). Renzo responds to this objection by claiming that both approaches are relevant in certain situations and that they must complement each other (Renzo, 2015: 583). However, he does not elaborate on this

\footnotetext{
${ }^{16}$ In this context, compare David Miller's claim (2007: 180) that it is needs that allow us to distinguish between what is essential and non-essential for human beings.
} 
idea any further nor does he adequately show how such complementarity could look. In conclusion, we can state that his theory cannot do without accepting certain preconditions that are not self-evident and on which there will almost certainly not be a consensus.

\section{III.3 The Relationship of Theories of Needs and Other Justification Approaches}

In connection with other needs-based justification approaches, there is an idea that such a justification may suitably complement other, different approaches. This is, for instance, advocated by Rita Floyd (2011: 103 - 115) who in one of her texts attempts to show how this concept can enrich the theory of James Griffin, Charles R. Beitz, and Beth Simmons. In this context, Floyd points out that the empirical approach of Beth Simmons is trying to prove that human rights treaties lead to the improvement of people's lives without sufficiently explaining what such improvement means (or what is meant by wellbeing) and what is its relationship to human rights (Floyd, 2011: 108). The theory of needs is, in her opinion, capable of filling this gap. Similarly as Rita Floyd treats human rights, Charles R. Beitz defines them by means of difficult-to-grasp elements such as, "urgent individual interests" (Floyd, 2011: 109). Replacing such a category with the concept of basic needs can contribute to the easier graspability and clarity of Beitz's theory (Floyd, 2011: 112 - 113). In connection with James Griffin, Rita Floyd warns us that Griffin himself admits that his approach can be understood to be based on needs or as protecting what we need to act as normative agents (Floyd, 2011: 112; Griffin, 2008: 90). These ideas can lead us to the consideration of whether some form of theory of needs can serve as a unifying framework for different theories that seek to justify human rights. I presume that if we understand needs in an instrumental sense, they could easily fulfil this role. However, if we considered them instrumentally, would they not be nothing more than an empty and very vague framework? Would they not lose what is important, what makes them specific as a justification concept?

In relation to other justification conceptions, we can also mention two main advantages of theories of needs. First, this concept can be easily acceptable for some nonWestern cultures. It is because some competing theories are based on assumptions that carry a much stronger cultural connotation. This is true about, for example, Griffin's theory based on autonomous agency, which according to Renzo, is too tied to the liberal concept of morality and can easily be rejected in the context of approaches emphasizing tradition, authority, or community (Renzo, 2015: 575, 583). ${ }^{17}$ David Miller also arrives at similar conclusions, and for the same reasons, perceives the justification concept based on the principle of self-ownership as problematic (Miller, 2012: 411). Another advantage of this approach may be seen in its greater flexibility. If we admit that one need does not always correspond to just one human right but that there is a whole set of basic needs that is protected by a whole set of human rights, then disagreement on some particular need does not necessarily lead to rejection of certain rights (Renzo, 2015: 586).

\footnotetext{
${ }^{17}$ Similarly, Jack Donnelly (1982: 313) treated human rights by comparing them with the idea of dignity, claiming that it could be more acceptable to many non-Western cultures.
} 
Another theory that is very close to the concept of basic needs is the capabilities approach. This approach is mainly associated with the names Amartya Sen and Martha C. Nussbaum. Both authors connect it with the concept of rights (Nussbaum, 1997: 276). Its more detailed analysis would deserve its own text. With regard to the narrower thematic focus of this paper and its possible scope, this approach will be only briefly described here. His creator is an Indian economist and philosopher Amatrya Sen who originally designed it as an alternative concept to welfare economics. Its purpose is to answer the questions: "What is the living standard? What is the quality of life?" (Nussbaum, 1997: 279). According to Nussbaum, the capabilities approach creates the best space in which we can compare how well individuals and nations live (Nussbaum, 1997: 285; Nussbaum, 2011: 18). Capabilities are based on the idea that not only the functions that people are currently performing are important. It is also important to make practical choices that people see as valuable. The starting point of the approach is the concept of functionings, which are activities that constitute a being of a person (e.g. that a person has a good health). The idea that a person can achieve different combinations of functions is the basis of capabilities. The capabilities approach focuses on what a person is actually able to do or to be, not what people feel (Nussbaum, 1997: 285; Nussbaum, 2011: 20). It focuses on opportunities that are available to every person. It does not concentrate on the total or average well-being. (Nussbaum, 2011: 18).

The political goal is not functioning but just the capability. For example, someone may decide to starve for religious reasons. Putting emphasis only on the functionings would thus lead to a restriction of the freedom of the people. They can decide how they live. Nussbaum explicitly states: "Citizens must be left free to determine their course after they have the capabilities.” (Nussbaum, 1997: 289). In the background of the capabilities approach is the idea of free citizens making choices (Nussbaum, 1997: 292).

While Sen did not create any list of capabilities, Nussbaum attempted to formulate it (Nussbaum, 1997: 285). On this list there are the capabilities that are crucial to human life. Central capabilities are not instrumental in character, but they have value in themselves. As Nussbaum writes, they make a life fully human (Nussbaum, 1997: 286). We also see here a connection with the idea of a good life. The list includes: life, bodily health, emotions, practical reason, affiliation (friendship, respect), other species, play, control over one's environment (political, material) (Nussbaum, 1997: 287-288; Nussbaum, 2011: 33-34). All of the above mentioned central capabilities are highly important and cannot be overlooked. Similarly to the various lists of basic needs, this could also be accused of being incomplete or arbitrary. However, Nussbaum does not claim that her list is final. She expects this list to be discussed and further improved (Nussbaum, 1997: 286).

The relationship between capabilities and rights may be different. In some cases, right and capability may overlap, sometimes it has the first priority and serves to protect the second (Nussbaum, 1997: 293). I find it inadequately clear how we can move from capabilities to norms. Having a certain capability does not necessarily mean that a person has the right relating to it. Nussbaum states in her text: "We are doing wrong to people when we do not secure to them the capabilities on this list.” (Nussbaum, 1997: 300). The 
acceptance of capabilities as something that must be protected by (human) rights, in my view, requires the acceptance of a certain normative premise, which, moreover, is echoed in the quote just quoted. The capability approach represents an interesting alternative to the concept of basic needs. They share common features, but in the case of the former they emphasize the liberal foundations of the whole concept (emphasis on the individual, his freedom and dignity). As we will see in the other parts of the text, the fundamental objection to it (unclear transition from facts to norms) can also be raise to the concept of basic needs.

\section{BASIC NEEDS AND THEIR RELATION TO THE CONCEPT OF RIGHTS}

\section{IV.1 The Problem of Uncertainty}

Of course, needs are not the same as rights. (Stewart, 1989: 350; Koller, 1997: 255) Yet they can represent a compelling basis. Or are they even capable of replacing rights in a certain context? To answer these questions, we must first take into account that authors who claim that they can, usually do not claim that one particular need should correspond to one particular right. On the contrary, they argue that there is a whole set of needs that is protected by a whole set of rights (Miller, 2012: 417; Renzo, 2015: 586). For example, the human need for social contact with other human beings establishes the freedom of movement, association, and expression (Miller, 2012: 417). This may eliminate some objections, such as that people have the need to eat and yet we would hardly find any explicit expression of this right anywhere.

However, there are other problems remaining which were critically addressed by Jeremy Waldron (2000). This author does not deny that arguing using claims of needs in the political forum can make sense (Waldron, 2000: 116). However, in his view they cannot replace the concept of rights as such, as proposed by Mark Tushnet to whom Waldron responds. ${ }^{18}$ In order to prove this thesis, he first deals with the argument that we do not agree on what rights we have, and if so, only on their very abstract formulation. ${ }^{19}$ In his text, Waldron seeks to show that the same is true of claims that we can deduce from needs and that also exhibit a high degree of uncertainty (Waldron, 2000: 119).

According to Waldron, we need some philosophy of human needs, and not only of biological needs if we are to seriously consider them as an alternative to the concept of rights (Waldron, 2000: 121). In my view, the same is true even if we are to consider them as their possible justification. In order to correctly understand what this thesis means, we need to take a closer look at the difference between these types of needs. For illustration, we can take the form of division to which Frederick Rosen refers in one of his works. In his opinion, needs can be divided into biological needs, i.e., those necessary for physical survival; basic needs, i.e., those essential for a decent life in society; and functional needs, i.e., those which must be satisfied so that one can do particular job.

\footnotetext{
${ }^{18}$ Specifically, Jeremy Waldron responds to Mark Tushnet's proposal contained in his text, An Essay on Rights, to replace the language of rights with the language of needs.

${ }^{19}$ The fact that formulations of human rights are usually very abstract, which opens room for their very diverse interpretation, was also noted by Eric A. Posner (2014: 31 - 32).
} 
Rosen criticizes and challenges, in particular, the division of biological and basic needs into two separate groups (Waldron, 2000: 121).

What makes the distinction between biological and basic needs difficult is the impossibility of defining the minimum standard ${ }^{20}$ without reference to a particular concept of life. If we define biological needs using the physical survival criterion, we certainly do not aim to merely survive until the next day. We can, of course, say that a person who does not have access to oxygen will die after five minutes, however, such narrowly conceived needs can hardly serve as the basis for an adequate human rights concept that, hyperbolically speaking, would not be centered around sufficient supply of oxygen. Therefore, we should rather aim for successful functioning in terms of a longterm framework, and it is true that the standard needed for survival will be very different if we live in a society that expects people to live on average for 50 years or in a society where people are expected to reach 80 years of age (Hapla, 2016: 49). If categories of needs are to be demonstrated in practice, they must be based on specific content. It is not very relevant that we have an abstract need to eat since in the real world we have to solve the question of what quantity and quality of food are acceptable in terms of needs. In the view of some authors, such a concretizing rule can only exist within society (Zetterbaum, 1977: 990). Yet, if it exists within society, it must also be relative to it. If it then refers to concepts such as, "bearable human life," which are very difficult to grasp (Waldron, 2000: 120 ), it is no more specific than all the vague formulations that rights are reproached for so often.

\section{IV.2 The Problem of Normativeness}

The category of human needs is therefore very vague. So what are the consequences of this fact? Jeremy Waldron notes that it is understandable that political concepts are such. It must be so, and our task is rather to understand them and to grasp all their advantages rather than to seek to eliminate their uncertainty by some definition (Waldron, 2000: 121). Such a procedure can be considered to be correct from a scientific point of view. It would prefer complex coverage of the situation, while the other procedure can easily slip into a search for a specific normative criterion and ideologization of the whole issue.

David Miller sees a key benefit of needs in that they are able to create obligations while other interests (regardless of their strength) are not. Miller admits, however, that this thesis stems only from his intuition and that he is unable to explain it (Miller, 2012: 422). Such admission, of course, does not give his idea much convincingness. Waldron sees the issue in a diametrically different way. When he compares the advantages and disadvantages of needs and rights, Waldron emphasizes that rights establish obligations for the other party (Waldron, 2000: 121). This interdependence of subjective rights and obligations, that is so emphasized by Wesley Newcomb Hohfeld, is logical and generally accepted in professional literature (Edmundson, 2012: 73; Ivison, 2008: 11 et seq.). In his view, we cannot say the same about needs. It is logically impossible to derive a normative

\footnotetext{
${ }^{20}$ The fact that the definition of the basic minimum is a problem was accepted by Stewart (1989: 348).
} 
obligation from needs. Waldron himself, however, later moderated this claim a bit. He explicitly states that he does not claim that the language of needs is purely descriptive and value-neutral. He does not deny its certain emotive undertones. He only refuses to admit its straightforwardly prescriptive character which he attributes to the language of rights (Waldron, 2000: 121).

Personally, I view this notion with reservations. As mentioned above, needs are of an instrumental character. While they are descriptive categories themselves, if they are to play any role in our thinking of rights, they must be derived from certain normative requirements, in particular the different ideas of dignified or good life, if not directly from some idea of the human nature. Therefore, it is not without reason that H. J. McCloskey warns us that if anybody rejects the idea that there is some general human nature, they should rather abandon consideration of needs as a basis of human rights (McCloskey, 1976: 2 and 6; Zetterbaum, 1977: 990). In his view, needs are logically and conceptually connected with the ideas of good existence and nature (McCloskey, 1976: 7), or, as Frances Stewart points out, they are instrumental to the idea of full life that we strive for (Stewart, 1989: 352). The views of both of these authors thus well correspond to the above-mentioned theses.

If we are interested in justifying human rights then we need to focus on the last sources of their normativity and perceive needs only as a certain intermediate element, a sort of gear wheel in a complex machine that transmits energy from the deepest of reasons into our concrete actions. On the other hand, the significance of needs can get a completely different dimension if we look at them from the perspective of persuasion, i.e., to what extent they have the potential in the real world to make someone change their attitude. If their position appears to us to be second-rate in terms of theory, they can play a very important role in practice - they can be a key argument that convinces key actors about the need to introduce some legal regulation or to issue a certain judicial decision. Below, we will try to take a look at why it is so. So far, let's stick with the matter of justification.

The concept of basic needs is closely related to the idea of human nature. Searching for the nature of man has been a traditional philosophical topic (Zetterbaum, 1977: 988). Knowledge of that nature would allow us to filter out various cultural specifics and thus, among other things, to give us a clear answer to the question of to what extent needs are culturally relative (Zetterbaum, 1977: 989). However, scepticism prevails over such a process, refusing to understand man as separated from the society in which they grew up and live. Remarkably, even some authors who look at this question not from a descriptive but normative point of view and who do not ask how basic needs are understood around world, but how they should be understood, claim that it is more useful to conceive them in practice as a socially relative standard (Stewart, 1989: 356). Although at the same time they very cautiously admit that some full life indicators can also generate universal standards (Stewart, 1989: 358). However, their universality is no longer based on ontology, but on other ideas. ${ }^{21}$ The idea of nature is then, to a varying

\footnotetext{
${ }^{21}$ Different types of universality in connection with human rights were addressed by Jack Donnelly (2007:
} 
degree, connected to the notion of good, dignified, or full life, in which there is always the problem of how to define it and what exactly we should imagine under that concept. Human dignity, ${ }^{22}$ good, etc., can be considered as good examples of essentially contested concepts. It can be assumed that our understanding of good, dignified, and full life will often overlap. All of these terms refer to the fact that we should strive for something more than just survival and that we are entitled to live a better life than just to exist. All of these concepts conceal in themselves a reference to certain aspirations. This, of course, leads to tension because many advocates of theories of needs tend to emphasize that the requirements they derive from needs are minimal (Renzo, 2015: 587). Good life can be understood as the broadest of these terms. The statement, "I live a good but not dignified life," may, of course, make a reasonable sense in certain contexts (e.g., the lives of most people in Huxley's Brave New World), but not if we try to think about the relationship between these terms from a generalizing point of view.

The question of how to define, measure, and monitor "full life" was asked, e.g., by Frances Stewart (1989: 355). This author sees the problem in its definition in finding its constitutive elements for which she considers health, nutrition, education, etc. (Stewart, 1989: 355). However, her view is fundamentally influenced by the viewpoint she took in examining the issue. She mainly aimed to define a standard for the needs of international law, especially in the context of the right to development of Third World countries. Within such a framework, her definition makes sense because there will be a broad consensus on the meaning of a full life that can be achieved. However, if we wanted to use such a definition to support, for instance, the issue of the constitutionality of paying fees at a doctor, that definition would be become too fragile and would hardly provide us with a basis for such a case. Objectively, we can hardly say what a good or dignified life is since there is no authority by which we could credibly justify our last values and points of view. This discord can be in some situations overlaid by social consensus as a product of historical randomness.

The foregoing leads us to the key thesis of our research, which is that the theory of needs does not help us to deal with the is-ought problem (McCloskey, 1976: 2). ${ }^{23}$ While we may encounter different constructions that could be perceived as attempts to deal with this deficit, I personally do not seem to be very successful. For example, in his text, Waldron states that we strike to satisfy our needs (Waldron, 2000: 123). Therefore, the primary normative requirement that is associated with needs is directed toward us. In other words: “"P needs $X$ ” implies "P should try to get $X$ ”” (Waldron, 2000: 123). However, this view can be easily misleading because it allows us to confuse our needs with our wants. It does not matter that we seek to satisfy our needs, but rather that we

282 et seq.). Donnelly mentions conceptual, substantive, anthropological, functional, international legal, overlapping consensus, and ontological universality. I believe that some of Donnelly's defined types of universality (e.g., functional) can be well related to the concept of human needs.

${ }^{22}$ This is well evident on the division of different, very often incompatible, types of dignity that Doris Schroeder (2012: 332 et seq.) uses in her work. Compare also the opinion of Pavel Ondřejek (2017: 2) who puts dignity into connection with Dworkin's interpretative concepts.

${ }^{23}$ It is worth mentioning that many other theories that seek to justify human rights are criticized for the same. For example, Joseph RAZ’s criticism of James Griffin’s approach (Raz, 2010: 325). 
should strive for them (which perhaps corresponds to Waldron's specifying formula, however, there is no explanation of why we should take such a normative requirement seriously). Need is linked to an objective character. One can have it without being aware of it. That is not true of our wants. We have the need to eat healthy, but we also have the want to have a duck with potato dumplings and beer for lunch. Efforts to satisfy that need are not straightforward. On the contrary, there is a great deal of effort in it that is largely motivated by the fact that the need is at the same time a significant normative requirement linked to a certain idea of good or dignified life that we accept. Thus, there is still a reference to another normative source whose relevance we cannot convincingly justify, and we ultimately support that need by only our own unwarranted beliefs. Similarly, when David Miller states that, "according to the needs approach, we prove that something is a human right by showing that having that right fulfils the needs of the right-holder," (Miller, 2007: 179) he does not explain why we should take the requirement that we should satisfy some needs seriously or what is the source of this norm that is a prerequisite for his theory (Miller, 2012: 422).

The concept of basic needs does not appear to be more justified than the human rights concept itself. In addition, it may have negative practical consequences. Let us recall in this connection the reproach that the theory that our rights can be deduced from some abstract right to satisfy our needs would lead to the claiming of too few rights (McCloskey, 1976: 2). ${ }^{24}$ This danger is mentioned, among others, by James Griffin who, as an example of a right that can be difficult to deduce from needs necessary for the normal functioning of the human body and mind, mentions the freedom of religion (Griffin, 2008: 89). David Miller also expresses the scepticism against the assertion that the concept of needs is able to generate all the rights that are part of today's human catalogues (Miller, 2012: 419 et seq.). However, he does not consider this situation to be problematic because the above-mentioned catalogues often have greater aspirations than just to provide a certain minimum list of human rights that would represent the minimum requirements of global justice (Miller, 2012: 420). Some human rights, as Miller claims, can also be justified by their necessity for the full realization of other human rights that stem directly from needs (Miller, 2012: 421).

To conclude, there is one more fundamental question to be raised: How much does the concept of needs have to be necessarily connected to the concept of rights? Could it be also connected with collectivist ideas that view individual rights with great reservations? Could we assume that meeting the needs of a larger group of people can justify that the needs of a smaller group of people are not met? The idea of rights excludes it, but why should it be excluded already by some theory of needs? If it were compatible with different systems that do not take seriously the rights of individuals, could we see it as an appropriate ground for justifying them?

\footnotetext{
${ }^{24}$ To this, compare also Amy Gutmann's claim that the growth in the number of human rights leads to the emergence of those that cannot be justified by reference to some of the traditional ways of justifying them, including the concept of basic needs (Gutmann, 2003: x).
} 


\section{CONVINCINGNESS OF BASIC NEEDS}

In the previous part of this text, we came to the conclusion that basic needs are not an adequate justification of the concept of rights. In spite of this, such an idea seems to be very intuitive and only few would contradict that they have the right to eat because eating is one of the basic needs of humans. It is possible to agree with Michael Neumann's view that some people simply think that rights are here to meet our basic needs, that the existence of such a need is in itself a sufficient basis for the moral right to satisfy it (Neumann, 1992: 354). Often, the argumentation using basic needs can therefore in practice be very persuasive and effective. We must ask the question why is it so. Why do we have such a strong idea that needs must be satisfied? And that we are automatically entitled to their satisfaction?

In his text, Jeremy Waldron puts forward a series of statements that could be perceived as relevant causes of said convincingness, provided he himself would not try to refute them later. For instance, Waldron says that the language of needs may sound more compassionate, more open, more responsive, and less aggressively individualistic (Waldron, 2000: 123). So it might seem more convincing because it is able to act more on our feelings. However, Waldron is highly sceptical about that (Waldron, 2000: 123). In any case, the stronger emotional effects can be generally perceived as one of the key convincing elements. ${ }^{25}$

Waldron (2000: 125) further notes that rights are in the general awareness associated with negative duties, while needs are associated with positive duties. Consequently, he refutes the distinction (Waldron, 2000: 126), which is not a difficult task because the fact that human rights establish duties of both types has been convincingly demonstrated by Henry Shue (1980: 17 and 52 et seq.). ${ }^{26}$ Shue is of the opinion that human rights basically establish three types of corresponding duties: to avoid depriving; to protect from deprivation; and to aid the deprived. The existence of all three duties is perceived as a condition for their effective functioning (Shue, 1980: 52 et seq.; Stammers, 1995: 496). But also Shue's theory has one flaw. In principle, it would be more accurate to say that every human right has the potential to generate both positive and negative duties - in fact, it does so to a varying degree in practice. From some rights, we infer rather negative duties and vice versa (Fabre, 1998: 273 - 275). For example, the right to freedom of speech could also result in a positive duty of the state to ensure the functioning of a public television and radio, although it has not been so at least in the current practice (Hapla, 2016: 47). Similarly, we can assume that even needs themselves do not only result in positive but also in negative duties (provided we accept that needs establish duties). For example, as concerns the need to drink, the state has not only the positive duty to provide people with access to a source of drinking water, such as digging a well, but also

\footnotetext{
25 The importance of the cultivation of some of our feelings (sentimental education) is also emphasized by Richard Rorty (1999: 739).

${ }^{26}$ Shue's theory was then put in deeper context by Sandra Fredman. Fredman (2008: 3 et seq.), for example, criticizes the traditional notion of freedom as absence of disruption and refers to a newer, much broader concept that allows us to illuminate the role of positive duties. Similarly, she also reconsiders other concepts that are behind the traditional linking of human rights with negative duties.
} 
the negative duty to refrain from limiting that need. It cannot send soldiers to prevent access to water to an ethnic minority etc. Connecting rights with negative duties, and needs with positive duties is thus illogical, however it may be true that such a connection is fixed in the minds of most people.

It seems that the great convincingness of the argumentation that uses needs will be hidden in something else. If we accept that there really is such a thing, we also invoke some objective framework. If we associate needs with a request, we want to imply that we do not call for it based on our whims. Our claim has some more fundamental basis that requires it to be generally respected. If there are two people who recognize the value of people's equality and accept that something like needs exists, although they do not have to agree on its content, they cannot simply disregard if one of them claims those needs. In addition, no one would probably say that their own needs should not be satisfied. In its very nature, the notion of need requires satisfaction - the problem is, in fact, the question of what we should consider as real needs and if there is such a thing at all. It is a concept that has the potential for everyone to use it since everyone has the interest that "their needs" are expressed. In principle, everyone recognizes some concept of life that such articulation will rely on. Needs are a concept that can be used in everyday life (though often in a shifted or inaccurate meaning), which cannot be said, for instance, about the concept of normative agency.

\section{CONCLUSION}

As is clear from the previous text, it is possible to raise a number of fundamental arguments against the theory of basic needs. However, the truth remains that every theory has its downside. Even if, for example, we stick to the theories of rights, we can only state that they need to clarify who and on what basis is the bearer of such rights (Andersson, 2012: 176), which many of them have not been very successful at. We need to assess the theory of basic needs in the proper context, and it is true that the notion that the rights are here to protect our needs is probably much more intelligible to most people than, for instance, the idea that these rights protect our normative agency. ${ }^{27}$ Each justification of human rights must have a starting point. We always have some starting points that others might view as unobvious - starting points we don't agree on. That is why the meaning of concepts that allow us, at least in part, to bridge such a disagreement in practice has been gaining importance. The example may be basic needs - although we can hardly agree on what the content is, they can serve as a suitable framework within which we can discuss our problems and discuss differing attitudes. David Miller points out that we agree on broad abstract formulations (e.g., the need for education) across cultures, but not on what they actually mean under certain circumstances (Miller, 2012: 415). This clearly points to the limits of such an agreement, yet it does not render it completely worthless. From the point of view of the role they can play in the political sphere, they may not seem to be completely redundant, though we do not really need them to justify human rights. The fact that such concepts are functioning successfully in a society can then prove society's

\footnotetext{
${ }^{27}$ For example, the foundationalist concept of human rights that we may otherwise consider to be one of the most elaborate and most coherent (Freeman, 1994: 505 et seq.; Griffin, 2008: 32 et seq.; Kohen, 2005: 49 $-75)$.
} 
stability and the presence of trust in its institutions. The concept of basic needs may not be a good ground for the justification of universal human rights, but it can be useful to us in a different way.

The great advantage of the concept of basic needs can be easily realized if we accept the thesis that it would be a mistake to understand our rights in isolation. Eric A. Posner notes that there is little evidence that international human rights treaties are conducive to increasing people's well-being or respect for the rights enshrined in these treaties. One of the main reasons for this is the erroneous assumption that good in each country can be reduced to a set of rules that can then be impartially enforced (Posner, 2014: 7). The question remains, how far can we relate this scepticism to the framework of national regulations that also enshrine human rights? However, this thesis illustrates well that the mere inclusion of legal norms in certain legal documents is not sufficient to put them into real practice. The effective functioning of law is thus linked to the successful functioning of other normative systems, as well as to the successful functioning of some (for most people perhaps more comprehensible) concepts that legitimize certain legal norms. One such concept can be variously treated basic needs on which we can successfully base the acquisition of human rights (not in theory, but) in practice.

\section{REFERENCES}

- ANDERSSON, Anna-Karin Margareta, 2012. Choices, Interests, and Potentiality. What Distinguishes Bearers of Rights? p. 176.

- BROZ, Jan and Pavel ONDŘEJEK, 2016. Pluralita dimenzí základních práv v současném státě. In: KYSELA, Jan; Pavel ONDŘEJEK et al. Kolos na hliněných nohou? K proménám státu a jeho roli. Prague: Leges, p. 202.

- CRUFT, Rowan; S. Matthew LIAO, and Massimo RENZO (eds.), 2015. Philosophical Foundations of Human Rights. 1st Edition. Oxford: Oxford University Press, p. xii, 702.

- DONNELLY, Jack, 1982. Human Rights and Human Dignity: An Analytic Critique of Non-Western Conceptions of Human Rights. The American Political Science Review. 76 (2), p 313.

- DONNELLY, Jack, 2007. The Relative Universality of Human Rights. Human Rights Quarterly. 29 (2), pp. 282 - 313.

- EDMUNDSON, William A, 2008. An Introduction to Rights. New York: Cambridge University Press, 2012, s. 73. IVISON, Duncan. Rights. Stocksfield: Acumen, pp. 11 et seq.

- FABRE, Cécile, 1998. Constitutionalising Social Rights. The Journal of Political Philosophy. 6 (3), pp. $273-275$.

- FLOYD, Rita, 2011. Why We Need Needs-Based Justification of Human Rights. Journal of International Political Theory. 7 (1), pp. 103 - 115. DOI: https://doi.org/10.3366/jipt.2011.0008

- FREEMAN, Michael, 1994. The Philosophical Foundations of Human Rights. Human Rights Quarterly. 16 (3), pp. 505 et seq. 
- FREEMAN, Michael, 2004. The Problem of Secularism in Human Rights Theory. Human Rights Quarterly. 26 (2), p. 392.

- FREDMAN, Sandra, 2008. Human Rights Transformed. Positive Rights and Positive Duties. Oxford: Oxford University Press, pp. 3 et seq.

- GRIFFIN, James, 2008. On Human Rights. 1st ed. Oxford: Oxford University Press, pp. $4-90$.

- GUTMANN, Amy, 2003. Introduction. In: IGNATIEFF, Michael. Human Rights as Politics and Idiolatry. Princeton University Press.

- HAPLA, Martin, 2016. Lidská práva bez metafyziky: legitimita v (post)moderní době. Brno: Masaryk University.

- KOHEN, Ari, 2005. The Possibility of Secular Human Rights: Alan Gewirth and the Principle of Generic Consistency. Human Rights Review. 7 (1), pp. 49 - 75. DOI: https://doi.org/10.1007/s12142-005-1002-3

- KOLLER, Peter, 1997. The Scope of Human Rights. In: KRAWIETZ, Werner, PATTARO, Enrico; ERH-SOON TAY, Alice (eds.). Rule of Law. Political and Legal Systems in Transition. Berlin: Duncker \& Humblot, p. 255.

- KYSELA, Jan, 2014. Ústava mezi právem a politikou: úvod do ústavní teorie. Prague: Leges, p. 258.

- MACMILLAN, C. Michael, 1986. Social versus Political Rights. Canadian Journal of Political Science / Revue canadienne de science politique. 19 (2), p. 288.

- MCCLOSKEY, H. J., 1976. Human Needs, Rights and Political Values. American Philosophical Quarterly. 13 (1).

- MILLER, David, 2007. National Responsibility and Global Justice. Oxford: Oxford University Press, pp. 179 - 187.

- MILLER, David, 2012. Grounding Human Rights. Critical Review of International Social and Political Philosophy. 15 (4), pp. 3 and $409-422$.

- NEUMANN, Michael, 1992. Needs Not Rights. Canadian Journal of Philosophy, pp. $353-354$.

- NICKEL, James W., 2007. Making Sense of Human Rights. Malden, MA; Oxford: Blackwell Pub, p. 1.

- NUSSBAUM, Martha C., 1997. Capabilities and Human Rights. Fordham Law Review, pp. 276-300.

- NUSSBAUM, Martha C., 2011. Creating Capabilities. The Human Development Approach. Cambridge, London: The Belknap Press of Harvard University Press, p. 18-34.

- ONDǨEJEK, Pavel, 2013. Several remarks on the legal aspects of human rights. In: ŠTURMA, Pavel (ed.). Pojem a teorie lidských práv. Prague: Charles University in Prague, Faculty of Law, p. 28.

- ONĎ̌EJEK, Pavel, 2017. The Many Faces of Human Dignity in Law. 2017, manuscript, p. 2. 
- POSNER, Eric A, 2014. The Twilight of Human Rights Law. New York: Oxford University Presspp. 6 - 7.

- RAZ, Joseph, 2010. Human Rights without Foundations. In: BESSON, Samantha; TASIOULAS, John (eds.). The Philosophy of International Law. Oxford: Oxford University Press, p. 325.

- RENZO, Massimo, 2015. Human Needs, Human Rights. In: CRUFT, Rowan; S. Matthew LIAO, and Massimo RENZO (eds.). Philosophical Foundations of Human Rights. 1st Edition. Oxford: Oxford University Press, pp. 572 - 587.

- RORTY, Richard, 1999. Human Rights, Rationality and Sentimentality. In: SAVIĆ, Obrad et al. The Politics of Human Rights. London: Versop. 739.

- SCHROEDER, Doris, 2012. Human Rights and Human Dignity. Ethical Theory and Moral Practice. 15 (3), pp. 332 et seq.

- SHUE, Henry, 1980. Basic Rights. Subsistence, Affluence and U.S. Foreign Policy. Princeton, New Jersey: Princeton University Press, pp. 52 et seq.

- STAMMERS, Neil, 1995. A Critique of Social Approaches to Human Rights. Human Rights Quarterly. 17 (3), p. 496.

- STEWART, Frances, 1985. Planning to Meet Basic Needs. London and Basingstoke: The Macmillan Press, pp. 1-5.

- $\quad$ STEWART, Frances, 1989. Basic Needs Strategies, Human Rights, and the Right to Development. Human Rights Quarterly. 11 (3), pp. 348 - 368.

- WALDRON, Jeremy, 2000. The Role of Rights in Practical Reasoning: "Rights" versus "Needs". The Journal of Ethics. 4 (1/2), pp. 116 - 129.

- WELLMAN, Carl, 2011. The Moral Dimensions of Human Rights. Oxford, New York: Oxford University Press, p. v.

- $\quad$ WIGGINS, David, 1998. Needs, Values, Truth. Oxford: Clarendon Press, pp. 617.

- ZETTERBAUM, Marvin, 1977. Equality and Human Need. The American Political Science Review. 71 (3), pp. 988 - 990. 